\title{
MANAGING ANNUAL ACCOUNTING REPORTS TO AVOID STATE TAXES: \\ AN ANALYSIS OF \\ PROPERTY-CASUALTY INSURERS
}

\author{
Kathy R. Petroni \\ Douglas A. Shackelford
}

Working Paper 6590

http://www.nber.org/papers/w6590

\section{NATIONAL BUREAU OF ECONOMIC RESEARCH 1050 Massachusetts Avenue \\ Cambridge, MA 02138 June 1998}

The authors acknowledge and appreciate comments by Ken Gaver, John Hand, Craig Lefanowicz, Mary Margaret Myers, and Robert Yetman and seminar participants at Michigan State University, the University of North Carolina, and the University of Wisconsin. Any opinions expressed are those of the authors and not those of the National Bureau of Economic Research.

(C) 1998 by Kathy R. Petroni and Douglas A. Shackelford. All rights reserved. Short sections of text, not to exceed two paragraphs, may be quoted without explicit permission provided that full credit, including $(\odot)$ notice, is given to the source. 
Managing Annual Accounting Reports to Avoid

State Taxes: An Analysis of Property-Casualty Insurers

Kathy R. Petroni and Douglas A. Shackelford

NBER Working Paper No. 6590

June 1998

JEL Nos. H25, H73, H71, G22, M41

\section{ABSTRACT}

We hypothesize that, in their annual accounting reports, insurers allocate premiums and losses from multistate policies to reduce total state taxes. To test this prediction, we examine firm-level data, collected from the publicly-available statutory reports used to compute tax bases and filed with each state government. If insurers manage allocations to avoid taxes, we anticipate an inverse relation between the tax rate and the premium-to-loss ratio, which is the industry's standard measure of the price of a unit of coverage. Firm-specific prices are computed using premium and loss information from the annual regulatory reports filed with each state in which an insur 


\section{Managing Annual Accounting Reports to Avoid State Taxes: An Analysis of Property-Casualty Insurers}

\section{Introduction}

This study extends our understanding of cross-jurisdictional tax planning by documenting reporting patterns in insurers' state annual accounting reports that are consistent with taxmotivated income shifting. Specifically, our findings are consistent with property-casualty insurers avoiding state taxes through strategically allocating premiums and losses across the statutory reports they file with each state in which they operate. Although the paper's primary inference-that companies shift tax bases across jurisdictions through allocations of income and expenses among commonly-controlled companies_-is similar to ones drawn from extant studies, its superior data enable a more powerful analysis of income shifting than has been previously possible. In addition, this paper is one of the first to identify the accounts through which income is shifted to avoid taxes.

Many prior studies (e.g., Klassen, et al. 1993; Harris 1993; Grubert, et al. 1993; Harris, et al. 1993; Jacob 1996; Collins and Shackelford 1997, Collins, Kemsley, and Lang 1997) produce indirect evidence consistent with income shifting. They infer multijurisdictional behavior from a single government's data (either publicly available SEC filings or confidential U.S. corporate income tax returns) and report associations between income and tax rates. Although several studies produce evidence consistent with income shifting, few specify how firms avoid taxes, leaving open the possibility that their results hinge on the omission of non-tax considerations that are correlated with taxes. 
At least two prior studies identify and test for specific multijurisdictional tax plans. Collins, Kemsley, and Shackelford (1997) use data from U.S. tax returns to examine shipments of inventory from foreign parents to U.S. subsidiaries in the wholesale trade industry. Contrary to expectations, they find no evidence of transfer pricing abuses. Klassen and Shackelford (1997) show firms avoid taxes by shipping manufactured goods from states with favorable taxation. However, their inferences are limited because they rely on non-tax return data, aggregated at the state level.

This paper analyzes firm-level data, collected from the publicly-available annual regulatory reports used to compute tax bases and filed with multiple governments. The high quality of the data enables the analysis to move beyond simply documenting income shifting to identifying the allocations tax planners could manage to shift income and assessing whether these accounts are managed. Its findings should interest accountants, tax planners, and insurers. Specifically, we hypothesize that, in their statutory reports, insurers allocate premiums and losses from multistate policies to reduce total state taxes. To test this prediction, reported premiums at the insurer-state level, scaled by incurred losses, are regressed on state tax measures. If allocations are managed to avoid taxes, we anticipate an inverse relation between the tax rate and the premium-to-loss ratio, which is the industry's standard measure of the price of a unit of coverage. Firm-specific prices are computed using premium and loss information from the annual regulatory reports filed with each state in which an insurer underwrites. Primary analysis is conducted on 12,573 insurer-state observations from 1993.

Consistent with income shifting to avoid state taxes, we find the price of propertycasualty insurance is decreasing in state tax rates. The results are consistent with multistate insurers managing their annual accounting reports to shift premiums (losses) to more (less) 
favorably taxed states. Additional tests using insurers operating only in a single state corroborate this interpretation. No negative relation is detected for single-state insurers. Inferences are cautiously drawn; however, because we only examine 180 single-state insurers and they may differ from multistate insurers along other dimensions.

The paper is organized as follows: The next section provides institutional background about state taxation of insurance companies and develops a testable hypothesis. Section 3 outlines the research design. Section 4 details the paper's findings. Concluding remarks follow.

\section{Background and Hypothesis Development}

Each insurer files an annual statement in each state it operates. These regulatory reports follow statutory accounting principles as developed by the National Association of Insurance Commissioners (NAIC) and include a balance sheet, a statement of income and many supplemental schedules and exhibits. Schedule T (Exhibit of Premiums Written--Allocated by States and Territories) includes direct premiums earned and direct losses incurred by state. Besides providing information for regulators and analysts, the statutory reports also are used to compute tax bases for state taxes. ${ }^{1}$ The empirical tests in this paper are designed to determine whether insurers manage the cross-state allocations of premiums and losses in Schedule T to reduce overall tax costs.

Four states (Florida, Illinois, New Hampshire, and New York) tax the profits of all property-casualty insurance companies underwriting within their borders. Connecticut, Kansas, and Oregon only tax the income of insurers incorporated in their states. The remaining states (and Connecticut, Kansas, and Oregon if the insurer is incorporated outside their borders) tax

\footnotetext{
${ }^{1}$ State taxes are not trivial. Petroni and Shackelford (1995) report that in 1990 the industry paid more to the states (\$7 billion) than to the U.S. Federal government ( $\$ 5.7$ billion).
} 
insurers' premiums. ${ }^{2}$ For both income and premium taxes, the applicable tax rate is the greater of the tax rate in the state where the insurance is sold and the tax rate in the state where the insurer is incorporated. This unique feature of insurance company taxation is known as retaliatory taxes (Petroni and Shackelford 1995).

Both premium and income taxes encourage insurers to shift premiums to states where the tax burden is lighter. The income tax also creates incentives for insurers to overstate total claims and other deductions. Understatement of total premiums is not a primary tax avoidance option because state revenue officials can measure premiums with considerable precision. Similarly, shifting losses across states is a limited tax strategy because state auditors can usually identify the state where a loss occurs.

Tax avoidance through shifting premiums is facilitated by the industry's reliance on inherently imprecise accounting allocations in the preparation of the statutory reports' Schedule T. For single-state policies, the reporting process is straightforward. If the policy is sold in the same state where the property is located and the insurer is incorporated, that state has sole authority to tax the policy's premiums or earnings. For multistate policies, insurers must allocate premiums across the states involved in the transaction. For example, if a group of affiliated hospitals in different states purchases a medical malpractice policy, the insurers must allocate the policy's income across the states where the hospitals are located, the policy is sold, and the insurer is incorporated. Insurers specializing in lines with more multistate policies likely have greater opportunities to avoid insurer taxes than other insurers because their reports rely more heavily on the Schedule T allocation.

\footnotetext{
${ }^{2}$ Some states tax both income and premiums and then permit one tax to be credited against the other tax. Private discussions with state revenue officials reveal that insurers in these states effectively face only the income or the premium tax. Consequently, no states in this study are treated as though both premium and income taxes apply.
} 
States provide little guidance concerning the allocation process. The process is sufficiently murky that Harrington $(1984,614)$ contends any state allocations "depend on arbitrary assumptions that might make the resulting figures meaningless." Private discussions with state revenue officials suggest tax audits primarily focus on determining whether all income is reported in some state. The allocations across states, which enable income shifting and are the focus of this study, reportedly receive less attention. Limited allocation regulations and enforcement lead to the paper's hypothesis, stated in its alternative form:

$\mathrm{H}_{1}$ : The premium-to-loss ratios that multistate insurers report to state tax authorities are decreasing in the marginal tax rate applied to their underwriting in the state.

Despite several factors suggesting Schedule T allocations are conducive to tax management, a countervailing implicit tax effect, inducing a positive relation between prices and taxes, biases against finding tax avoidance in this setting. Assuming competitive conditions and no tax-motivated management of the Schedule $\mathrm{T}$ allocations, the price of insurance should be bid up (down) in states that tax property-casualty insurers less (more) favorably until the after-tax returns to investing in underwriting are identical across all states. To achieve such equality, before-tax returns increase in state tax levies (Scholes and Wolfson 1992; Shackelford 1991; Guenther 1994). To the extent premiums and losses reflect adjustments in before-tax returns, our estimates of tax-motivated income shifting will be understated.

\section{Research Design}

\section{Dependent Variable}

To determine whether multistate insurers avoid state taxes through strategic allocations in the statutory reports, insurance prices are regressed on measures of state taxes, controlling for previously documented price determinants: 


$$
\begin{aligned}
& \text { PRICE }_{i j}=\beta_{0}+\beta_{1} \text { tax measures } \\
& \text { for all insurers } i \text { and states } j .
\end{aligned}
$$

The dependent variable, PRICE, is the insurer's premiums less policyholder dividends divided by losses incurred (including estimated unpaid claims at year-end) as reported in Schedule $\mathrm{T}$ of the annual regulatory reports. This premium-to-loss ratio is recognized within the insurance industry as the ex post price of a dollar of coverage. A superior dependent variable would be the ex ante price of insurance; however, we are unaware of readily available data that would permit us to compute ex ante prices. Using an ex post measure is only problematic if unanticipated catastrophes occur disproportionately in states with similar tax structure. To mitigate this concern, the study is limited to 1993, a year without major earthquake or hurricane damage. ${ }^{3}$

For the insurer-states that do not face income taxation, an ideal dependent variable would include only premiums because losses do not affect tax liabilities in those states. However, if the sample is restricted to those insurer-states and premiums are used as the dependent variable, a scalar is needed to control for heteroskedasticity, and the most appropriate scalar is losses. Thus, the premium-to-loss ratio probably is the best dependent variable for assessing premium tax avoidance. Moreover, for the insurer-states facing income taxes, losses are the largest deduction. The ratio also controls for the possibility that some premiums are inseparable from their associated losses for shifting purposes and thus of limited use in avoiding income taxes. On the other hand, to the extent insurers mask premium tax avoidance by shifting both losses and premiums, PRICE may reduce the power of the tests to detect premium tax management.

\footnotetext{
3 In 1993 eight states suffered losses in excess of \$500 million from floods of the Mississippi and adjoining rivers. Inferences are unaltered when the insurer-states in these eight states are excluded from the analysis.
} 


\section{Tax Variables}

The ideal tax measure is the marginal tax rate each property-casualty insurer faces in each state. Unfortunately, the data do not permit such fine calibrations. Instead, we employ two alternative measures to approximate marginal tax rates: the effective (or average) state tax rate on insurers and the estimated statutory (premium and income) tax rates. To determine the relevant tax rate for each insurer-state, insurers' unique retaliatory tax structure must be incorporated in the tax measures. Thus, the insurer-state tax rate is the greater of the tax rate in the state where the insurance is sold and the tax rate in the state where the insurer is incorporated. ${ }^{4}$ Negative coefficients on the tax measures are consistent with tax management of the annual statements.

The first tax measure is the effective tax rate in each state, i.e., the total taxes (premium and income) collected from all insurers within the state as a percentage of total premiums. ETR for an insurer-state is the greater of the effective tax rate in the state where the policy is written and the effective tax rate in the state where the insurer is incorporated. Petroni and Shackelford (1995) employ this tax measure because it enables them to convert various state systems for taxing insurers to one comparable measure. Unfortunately, ETR masks cross-insurer rate differences and includes taxes and premiums from life and health insurance companies. Petroni and Shackelford (1995), however, assert that the inclusion of life and health insurers should not materially affect inferences because states tax the two sectors similarly. ETR also fails to distinguish between insurer taxes arising from premium taxes and insurer taxes arising from income taxes.

To provide some segregation of these effects, a variable indicating the presence of an income tax in the state (INCDUM) is included in the regressions using ETR as an explanatory 
variable. No prediction is advanced for INCDUM because it is unclear whether prices are lower in income tax states or premium tax states. ${ }^{5}$

ETR also is modified to assess the sensitivity of tax avoidance to insurance lines. EASYETR is ETR for the insurers writing greater than 75 percent of their business in lines other than automobile, farm, fire, home, and workers' compensation and zero for other insurers. Specifically, these insurers concentrate their business in liability, medical malpractice, reinsurance, and credit and surety lines. EASYETR's coefficient is expected to be negative, consistent with increased tax management in lines with more opportunities for Schedule $\mathrm{T}$ crossstate allocations. The first four lines involve insured property confined largely to a single state. Workers' compensation is the most tightly regulated line of insurance. In fact, some states require its purchase from state workers' compensation funds. Consequently, insurers have limited opportunity to allocate workers' compensation insurance across states.

The second set of tax measures provides more precise segregation of premium tax and income tax effects. They are the statutory premium tax rates (PREMRATE) and income tax rates (INCRATE) applicable to each property-casualty insurer-state. To the extent tax bases and tax credits vary across states, statutory tax rates measure marginal tax rates with error. A casual review of state tax systems suggests that states vary considerably along both dimensions. In particular, 16 states provide rate reductions if insurers invest substantially in state securities, employ state residents, establish regional offices in the state, etc. If the insurer is incorporated in

\footnotetext{
${ }^{4}$ Five percent of the sample involves observations from the insurer's state of incorporation.

${ }^{5}$ Income taxes, unlike premium taxes, are reduced by loss overstatement as well as premium understatement. Consequently, insurers may avoid income taxes more easily than premium taxes. If so, the coefficient on INCDUM should be negative.
} 
the state, we assume the insurer qualified for the most favorable tax rate available. In all other cases, we assume the insurer did not qualify for any rate reduction. ${ }^{6}$

\section{State-specific Control Variables}

A large literature has investigated the determinants of insurance prices. Several control variables are included in the paper's regressions to ensure that these non-tax determinants do not affect our inferences about the effects of state taxes on insurance prices. The first set of control variables addresses cross-state variation in the price of insurance.

Two variables are used to control for the effects of product sales regulation on prices. ${ }^{7}$ The first regulatory control variable is RATEREG, a categorical variable indicating whether the state is one of the 26 that regulate insurance rates. The second regulatory control variable is RESTRICT, which ranks each state from one to 51, based on Conning \& Company's survey of insurance managers in 1991. The survey assesses the relative freedom among states to manage personal and commercial lines of business. The higher the ranking, the more restrictions the state places on insurers' ability to design, price, and market their products.

Negative coefficients are expected on RATEREG and RESTRICT. In his survey of the numerous empirical studies evaluating the effects of state regulation on insurance prices, Harrington (1984) concludes that the evidence generally is consistent with insurance rates decreasing in the stringency of state regulatory oversight. Similarly, Vines (1996) reports that customers in rate-regulated states bore less of the industry's Federal income tax increase following the Tax Reform Act of 1986 than customers in other states.

\footnotetext{
6 Inferences are unchanged if the average of the maximum statutory tax rate and the most favorable statutory tax rate is used.

7 Product sales regulations include prior approval of rates and guidelines concerning trade practices, insurance policies and contracts, advertising, marketing, cancellation of policies, and other operating practices.
} 
Negative relations between PRICE and the product sales regulation variables also are expected because insurers have incentives to manage the statutory reports to appear less profitable in rate regulated states. Regulators use the same financial information that determines tax bases to evaluate an insurer's profitability. In high-tax, rate regulated states, the tax and regulatory incentives are aligned, increasing the returns to premium understatement and (in income tax states) loss overstatement. In low-tax, rate regulated states, tax and regulatory incentives conflict. ${ }^{8}$

NOFAULT is a categorical variable indicating whether the state is one of the 14 with nofault automobile coverage. Because Witt and Urrutia (1983) find the price of automobile insurance is less in states with no-fault insurance, a negative coefficient is expected for NOFAULT.

INSPOP is number of insurers per 1000 people in the state. Browne and Hoyt (1995) find that a 10 percent reduction in the number of property-casualty insurers results in an 82 percent reduction in the industry's insolvency rate. They interpret this finding as evidence that fewer insurers result in less competition and higher prices. To the extent INSPOP captures competition, its coefficient is expected to be negative.

\section{Insurer-specific Control Variables}

The remainder of the control variables addresses cross-insurer variation in the price of insurance. DIRWRITE is a categorical variable indicating whether the insurer directly sells its policies, as opposed to using independent agents. Several studies (e.g., Joskow 1973; Cummins

\footnotetext{
8 See Scholes, et al. (1990), Collins, et al. (1995), Beatty, et al. (1995), and Collins, Geisler, and Shackelford (1997) for examples of studies addressing the coordination of multiple incentives, including taxes, regulatory capital and earnings.
} 
and VanDerhei 1979; Cummins, et al. 1980; and Witt and Miller 1981) report the price of insurance decreases in the presence of direct writers. Accordingly, a negative coefficient on DIRWRITE is expected.

SIZE is the natural logarithm of the insurer's admitted assets. ${ }^{9}$ Larger insurers can charge lower prices because they can amortize their fixed costs over a larger pool and diversify their risks more easily. Thus, PRICE is expected to be decreasing in SIZE.

Sommer (1996) reports a positive relation between the price of insurance and the insurer's capitalization and a negative relation between price and the insurer's investment portfolio volatility. He infers from these relations that prices are decreasing in an insurer's solvency risk. To control for such effects, the regression includes two measures of solvency risk. CAPITAL is an insurer's statutory surplus divided by its total admitted assets. PORTRISK is the percentage of an insurer's assets in more volatile investments, namely equity, unoccupied real estate and mortgage loans. ${ }^{10}$ PRICE is predicted to be increasing in CAPITAL and decreasing in PORTRISK.

The final controls are a vector of measures denoting the insurer's percentage of propertycasualty underwriting in accident and health, automotive, credit and surety, liability, medical malpractice, reinsurance, and worker's compensation. All remaining lines are combined. The lines of business are included in the regression to control for possible price variations across lines. No predictions are advanced for the coefficients on the lines of business.

\footnotetext{
${ }^{9}$ Total admitted assets are total assets less furniture, equipment, automobiles, accounts receivable not taken from premiums, and investments not meeting return requirements or made in excess of permissible limits.

10 Results are qualitatively unaltered when the numerator of PORTRISK excludes equity.
} 


\section{Data and Sample}

Each insurer's financial data, state of incorporation, and the number of insurers operating in each state are collected for 1993 from the NAIC Property/Casualty Annual Statement Database. ${ }^{11}$ Each state's total taxes collected from insurance companies are gathered from the NAIC Insurance Department's Resources Report for 1993. Information regarding state taxation of insurance companies is gathered from the NAIC publication, Retaliation: A Guide to Retaliatory Taxes, Fees, Deposits, and Other Requirements. Information regarding the state regulation of insurance prices is collected from a 1989 NAIC rate regulation survey. The states with no-fault insurance are identified in Insurance Information Institute's 1993 Fact Book. Direct writers are identified based on a list of no-fault insurers in 1993 supplied by the A.M. Best Co. The population of each state in 1993 is collected from the 1994 U.S. Statistical Abstract.

The sample is limited to property and casualty insurance companies that operate in more than one state (multistate insurers). The sample is further restricted to stock insurers, the industry's principal ownership structure, to control for possible variation across organizational forms (e.g., see Mayers and Smith 1988, 1994). The data produce 19,239 insurer-states in 1993. Observations with extreme values of PRICE (less than one-half or greater than three) are deleted from the sample, leaving 12,573 insurer-states. ${ }^{12}$ They include 920 insurers with the median insurer underwriting in nine states.

\footnotetext{
${ }^{11}$ Data source: NAIC, by permission. The NAIC does not endorse any analysis or conclusions based on the use of these data.

12 Inferences are insensitive to restricting the sample to either positive values of PRICE less than five or positive values of PRICE less than ten.
} 


\section{Descriptive Statistics}

Table 1 presents descriptive statistics for the regression variables. Mean and median PRICE is 1.61, reflecting a 61 percent markup from losses on insurance products. ETR ranges from 0.6 percent to 2.8 percent with a mean and median value of 1.5 percent, indicating that, on average, insurers remit 1.5 percent of a policy's premiums in state taxes. Ten percent of the insurer-state observations are from the seven states that levy income taxes on property-casualty insurers. Mean (median) PREMRATE is 2.4 (2.3) percent. Mean INCRATE is 0.6 percent, implying that the 1,222 observations from states with insurer income taxes face an average income tax rate of 6.4 percent.

\section{INSERT TABLE 1}

The descriptive statistics for the control variables show 39 percent of the sample is in rate regulated states, indicating the sample is disproportionately in the 25 states that do not regulate insurance rates. Twenty-seven percent of the sample is in the 14 states with no-fault automobile insurance. INSPOP ranges from 0.03 to 1.24 , indicating wide variation in the number of insurers per state, after controlling for population. Twenty percent of the insurers are direct writers. Insurance company assets range from $\$ 1$ million to $\$ 28$ billion. The mean (median) insurer reports assets of $\$ 1$ billion ( $\$ 200$ million). Statutory surplus averages one-third of total admitted assets. On average, equity, unoccupied real estate, and mortgage loans account for $14 \%$ of total invested assets. 


\section{Univariate Analysis}

Consistent with the annual statements being managed to reduce state taxes, Table 2's Pearson correlation coefficients for PRICE and ETR and for PRICE and INCRATE variables are negative (-0.03) and significant at the 0.05 level. The correlation between PRICE and PREMRATE is not significantly different from zero.

\section{INSERT TABLE 2}

The signs of the Pearson correlation coefficients between PRICE and every control variable, except PORTRISK, are consistent with prior findings. Contrary to expectations, the correlation between PRICE and PORTRISK is positive, though not significantly different from zero. The statistically significant correlations between the tax and control variables suggest that: (1) Rate regulated states are less likely to impose income taxes on insurers. (2) No-fault states have lower premium taxes and higher income taxes. (3) Premium (income) taxes are increasing (decreasing) in the number of insurers per capita.

\section{Results}

ETR

The regression results in Table 3 present evidence that is consistent with propertycasualty insurers managing their accounting reports to mitigate tax costs. ${ }^{13}$ In the tests conducted using multistate insurers (columns A-E), the regression coefficient estimates on ETR,

13 Table 3 reports $t$-statistics using White's adjusted standard errors when the null hypothesis of correct model specification under White's (1980) test is rejected at conventional levels. Inferences are unaltered, however, if no corrections are made. 
PREMRATE and INCRATE are always negative, as predicted, and significant with $t$-statistics ranging from -1.90 to -4.41 .

\section{INSERT TABLE 3}

Column A reports the summary statistics for ETR, INCDUM, and eight previously documented price determinants. Coefficient estimates are not reported for the eight lines of business. The regression coefficient on ETR is -5.33 with a $t$-statistic of -4.41 , consistent with reported prices falling in state insurer taxes. The coefficient implies that a one standard deviation increase in the effective state tax rate (0.005) decreases the reported premium-to-loss ratio by $0.027(-5.33 * 0.005)$. Evaluated at the mean PRICE of 1.61 , the finding indicates that insurers respond to a standard deviation increase in ETR by understating the insurance prices they report to state regulators and tax officials by 1.7 percent $(0.027$ / 1.61).

These estimates assume the formation of implicit taxes exerts no upward pressure on prices when taxes are increased. To estimate implicit tax effects, let A be the after-tax return all insurer-states face, let $\mathrm{P}$ be the pre-tax return for insurer-state $\mathrm{i}$, and $\tau$ be the tax rate in insurerstate i. In all insurer-states, $A=P_{i}\left(1-\tau_{i}\right)$ and $\delta P / \delta \tau=P /(1-\tau)$. Evaluating $P$ at the mean value for PRICE (1.61) and $\tau$ at the mean value for ETR (0.015), the derivative is 1.63. Thus, a one standard deviation increase in ETR (0.005) would be expected to increase PRICE by 0.008 $(1.63 * 0.005)$.

Subtracting the 0.008 implicit tax-induced price increase from the earlier estimate of the reduction in the premium-loss ratio following a one standard deviation drop in ETR (-0.027), yields a total price reduction of -0.035 . Dividing this sum by mean PRICE suggests insurers 
would understate the insurance prices they report to state regulators and tax officials by 2.2 percent (-0.035 / 1.61) if ETR were decreased by a standard deviation. In summary, including an estimate of implicit taxes increases the estimated tax-avoidance price response by $29 \%$ [(2.21.7)/1.7].

The estimated regression coefficient for INCDUM implies that insurer-states facing an income tax report 5.4 percent $(-0.087$ / 1.61) lower insurance prices than insurer-states facing a premium tax. INCDUM's negative coefficient is consistent with insurer-states that face income taxes engaging in more price understatement than other insurers.

\section{EASYETR}

Column B shows the coefficients when EASYETR is included as a regressor. Recall EASYETR is intended to identify insurers that underwrite primarily in lines with the most opportunity for avoiding taxes through cross-state allocation of multistate policies. Sixteen percent of the sample involves insurer-states with a positive value for EASYETR, i.e., write greater than 75 percent of their business in lines other than automobile, farm, fire, home and workers' compensation.

The regression coefficient in Column B on EASYETR is -5.35 ( $t$-statistic $=-3.74)$, consistent with lower reported prices by insurers specializing in lines where opportunities are greater to avoid taxes. Combining the ETR and EASYETR coefficients, the estimated lowerbound response (no implicit taxes) for these insurers to a one standard deviation increase in the effective state tax rate is a 0.049 decrease in the reported premium-to-loss ratio or a 3.0 percent drop in reported insurance prices. The corresponding estimated upper-bound response (assuming 
full implicit tax effects) is a $0.057(0.049+0.008)$ decrease in the reported premium-to-loss ratio or a 3.5 percent drop in reported insurance prices.

\section{PREMRATE and INCRATE}

Column C shows that the coefficients on PREMRATE (-1.83 with $t$-statistic of -1.90$)$ and INCRATE (-0.94 with a $t$-statistic of -3.57$)$ are consistent with state premium tax and income tax avoidance, respectively. The results using statutory tax rates confirm the earlier findings using effective tax rates. A standard deviation increase in the PREMRATE (0.006 percentage points) reduces reported insurance prices by 0.7 (2.1) percent assuming no (full) implicit taxes. ${ }^{14}$ INCRATE's coefficient implies that a one percentage point increase in a state's income tax rate would decrease reported insurance prices by 0.6 (1.0) percent assuming no (full) implicit taxes. ${ }^{15}$

\section{Control Variables}

With one exception, the signs of the other regression coefficient estimates are as predicted. The coefficients on RATEREG and RESTRICT are negative, consistent with both prices being suppressed and profits being underreported in states with more restrictive product sales regulation. The coefficient on NOFAULT is negative, consistent with prior studies indicating lower prices in states with no-fault automotive insurance. INSPOP's coefficient is

\footnotetext{
14 The price effect including implicit taxes is $-0.021=0.006 *\{-1.83-[1.61 /(1-0.024)]\}$. Mean PREMRATE is 0.024 . 15 To include implicit taxes in determining the economic significance of the income tax avoidance, a modification of $\delta \mathrm{P} / \delta \tau$ is required. Let the pre-tax return $(\mathrm{P})$ equal the mark-up to losses (premiums less losses). (Data constraints limit the analysis to the primary sources of income and deductions, ignoring other income and deductions used to determine taxable income.) Mark-up is the mean value for premiums (1.61) less the mean value for losses (1.00). Evaluating the derivative with pre-tax returns of 0.61 and the mean tax rate facing insurers in income tax states (0.064) to estimate the tax rate, implicit taxes cause a one percentage point increase in $\tau$ to increase $P$ by 0.007 $[0.61 /(1-.064)] * 0.01$.
} 
negative, consistent with prices falling in the presence of increased competition. The coefficient on DIRWRITE also is negative, confirming prior findings that insurers who directly sell their policies offer lower prices. The coefficient on SIZE also is negative, suggesting larger insurers offer lower prices. CAPITAL's coefficient is positive, consistent with less capitalized firms having to accept lower prices in response to buyers' concerns about their insolvency.

The sole control variable with the wrong sign is PORTRISK. Consistent with Sommer (1996), we anticipated insurers with riskier investments would be forced to lower the price of their insurance in response to buyers' concerns about their insolvency. However, consistent with the positive correlation coefficient between PRICE and PORTRISK, the regression coefficient on PORTRISK is positive. Differences in Sommer (1996) and our measures of portfolio risk may explain the different results. ${ }^{16}$ However, this control does not appear to affect the paper's inferences. Quantitative results are almost identical when the regression is reestimated, excluding PORTRISK from the explanatory variables.

The regression coefficient estimates for the lines of business are not presented in Table 3, and we offered no predictions concerning their signs. However, the coefficients on the accident and health, reinsurance, and worker's compensation lines are negative and significant at conventional levels, suggesting that markups are smaller in these lines. The coefficients on the credit and surety, liability and miscellaneous lines are positive and significant, implying markups are larger in these lines. ${ }^{17}$

\footnotetext{
16 Sommer (1996) measures portfolio risk by estimating the investment portfolio standard deviation. He uses estimates of the insurer's asset and liability volatilities and the correlation coefficient between the asset and liability processes to quantify a risk parameter from option pricing. Sommer (1996) asserts that his measure is an improvement over the typical approaches used to determine portfolio risk, such as our method. Unfortunately, his measure would require acquisition of prohibitively expensive data from multiple years for our sample. Sommer limits his sample to 142 insurer groups and uses quarterly time series data from 1975 to 1989 . With our large sample, we adopt the simpler industry standard in computing PORTRISK.

17 To control for the possibility that purchases of lines vary across states, sensitivity tests include state lines of business. The vector of state line variables measure the percentage of each line of business aggregated at the state
} 


\section{Robustness Tests}

Columns D and E report the results from two tests of the robustness of the results to different specifications. Conclusions are qualitatively unaltered by the results in these two regressions. Column D uses a separate intercept for each insurer instead of insurer-specific controls (DIRWRITE, SIZE, CAPITAL, PORTRISK, and lines of business). The tax measures remain negative and highly significant. The coefficient on ETR is -4.07 with a $t$-statistic of -3.07 . The coefficient on INCDUM is -0.063 with a $t$-statistic of -3.73 .

Column E presents summary statistics from an alternative estimation procedure undertaken to assess whether the $t$-statistics in the earlier regressions are overstated. Because our sample includes multiple observations for every insurer, the OLS residuals likely are contemporaneously correlated, potentially biasing the standard errors (Bernard 1987). To assess the extent of the bias, we estimate standard errors by applying the Froot (1989) technique. The Froot (1989) standard errors account for intra-insurer correlations in the residuals of each insurer and heteroskedasticity. They are consistent and asymptotically efficient.

To limit computational demands, we apply the Froot technique to the regression reported in Column A, excluding CAPITAL, PORTRISK, and the eight lines of business variables. ${ }^{18}$ The OLS coefficient estimates from this modified model are essentially identical to those reported in Column A. The Froot adjusted standard errors are generally higher than the OLS standard errors, but the significance of the $t$-statistics is qualitatively unchanged. In short, any

\footnotetext{
level as a percentage of the state's total insurance business. When the state lines of business are included as regressors with the other explanatory variables in Column A, only the coefficient on the miscellaneous line is significant at the 0.05 level.

18 We were unable to secure computational capacity that would permit estimation of the entire model reported in Column A using the Froot (1989) technique. Criteria for discarding control variables were (1) variables without a predicted sign (eight lines of business), (2) variables whose coefficients have the wrong sign in Column A (PORTRISK) and (3) among variables whose coefficients have the predicted sign, the one with the smallest $t$ statistic (CAPITAL) in Column A.
} 
interdependencies caused by multiple observations for insurers neither overstate the statistical significance of our results nor affect the inferences drawn from OLS regressions.

\section{Single-state insurers}

If the tax management hypothesized in this paper exists, i.e., tax-motivated cross-state allocations of premiums and losses in the statutory reports filed with state officials, then the coefficients on the tax variables should not be negative if the tests are conducted using a set of insurers that file with only one state. Forced to report all premiums and losses from all underwriting in a single state, these insurers could not avail themselves of a tax management strategy that requires multistate filings. Column F reports the results from estimating the regression equation using 180 insurers who only underwrite in their state of incorporation and are unaffiliated with any insurers in other states.

When the sample is restricted to single-state insurers (Column F), the tax coefficients are positive, though not significantly different from zero. The failure to find significantly negative tax coefficients using single-state insurers provides further evidence that multistate insurers are reducing taxes through manipulation of Schedule T. The absence of a negative sign on ETR in Column F's results implies multistate insurers enjoy a competitive advantage, compared with single-state insurers, because they can access a tax reduction strategy unavailable to single-state insurers.

However, the results from the single-state regression must be interpreted cautiously. Unlike the multistate estimates, none of the coefficients on the explanatory variables, except RATEREG, is significantly different from zero. The poor specification is consistent with both inadequate power from the smaller single-state insurer sample and unspecified differences in the 
price determinants of multistate and single-state insurers. In particular, the known price determinants, which serve as explanatory variables in this study, largely come from analyses of multistate insurers. Thus, the single-state tests only provide qualified support of income shifting through multistate allocations.

\section{Other specification checks}

The findings in this study are robust to a battery of additional specification checks. One, some states permit insurers to credit guaranty fund assessments against premium taxes. In those states, the statutory tax rate likely overstates the premium tax burden, and insurers have an incentive to overstate premiums. To assess the effect of guaranty fund assessments on the findings, the regression model was reestimated excluding insurers from six states (Arizona, Florida, Georgia, Hawaii, Louisiana, and Texas) that account for 82 percent of all assessments in the U.S. ${ }^{19}$ Inferences are qualitatively unaltered.

Two, to control for possible cross-state variation in the demand for insurance, we added the gross state product per capita (as reported in the 1997 U.S. Statistical Abstract) as a regressor. Its coefficient is not significantly different from zero, and its inclusion did not overturn any prior inferences.

Three, the correlation matrix in Table 2 shows no relation between the tax variables and RESTRICT, a measure of a state's regulatory climate. However, it is conceivable that state tax avoidance might be curtailed in more regulated states. To assess whether tax management varies with an insurer's operational freedom, we interacted ETR with a categorical variable determined by whether the state's RESTRICT value exceeded the mean RESTRICT value. When the

\footnotetext{
191993 guaranty fund assessments were collected from the Insurance Information Institute's 1995 Fact Book.
} 
interaction term is included in the regression, it is not significantly different from zero and other coefficients are qualitatively unaffected.

Four, to determine whether the results vary between large and small insurers, we segregate the sample into the 8,860 insurer-states with greater than $\$ 500,000$ in premiums and the remaining 3,713 smaller insurers. Conclusions about the effect of state taxes on insurance prices do not vary between subsamples.

\section{Conclusion}

This paper attributes an association between insurers' premium-to-loss ratios and state taxes to the allocation of premiums and losses by multistate insurers. Insurers likely find this form of income shifting efficient because it is largely unimpeded by stringent state guidelines or enforcement. To our knowledge, this study is the first to document income shifting using firmlevel data, collected from the publicly-available accounting reports used to compute tax bases and filed with multiple governments. Although documentation of income shifting is not unique, the quality of the data and the ability to specify how income shifting is accomplished distinguish this paper from prior income shifting studies.

The paper also contributes to our understanding of the insurance industry by showing that state tax planning extends beyond the initial expansion decision (Petroni and Shackelford 1995) to include management of the annual regulatory reports. The findings raise questions about the reliability of the industry's statutory reports. This demonstration of tax manipulation should be of particular interest to regulators, who rely on the annual statements to establish rates and assess solvency, rating agencies that rely on the accounting reports to assess solvency, and analysts, who rely on the accounting reports to differentiate among products. 
Finally, by including implicit taxes in its estimates of income shifting, this paper is the first, to our knowledge, to consider jointly the negative price-tax relation induced by taxmotivated income shifting and the positive price-tax relation induced by the formation of implicit taxes. Prior income shifting studies have ignored implicit taxes, potentially understating tax manipulation.

More explicit recognition of the countervailing forces of income shifting and implicit taxes is needed to advance our understanding of both effects. Although employing similar tests, the two lines advance opposite predictions of the price-tax relation. The critical distinction appears to be an ex ante assessment of the quality of the price data. Income shifting studies examine self-reported data (from financial statements or statutory reports) that are subject to manipulation. Tax shifting studies use independent price measures that are not easily managed, e.g., Shackelford (1991) uses bank loans and Guenther (1994) uses Treasury bills. Future research should consider more formal theoretical underpinning for the predicted price-tax relation. 


\section{References}

Beatty, A., S. Chamberlain, and J. Magliolo. 1995. Managing financial reports of commercial banks: The influence of taxes, regulatory capital, and earnings. Journal of Accounting Research 33: 231-261.

Bernard, V. 1987. Cross-sectional dependence and problems in inference in market-based accounting research. Journal of Accounting Research 25: 1-48.

Browne, M. and R. Hoyt. 1995. Economic and market predictors of insolvencies in the propertyliability insurance industry. Journal of Risk and Insurance 62: 309-327.

Collins, J., G. Geisler, and D. Shackelford. 1997. The effects of taxes, regulation, earnings, and organizational form on life insurers' investment portfolio realizations. Journal of Accounting and Economics, 24:3, forthcoming.

, D. Kemsley, and M. Lang. 1997. Cross-jurisdictional income shifting and earnings valuation. University of North Carolina working paper.

, and D. Shackelford. 1997. Transfer pricing and the persistent zero taxable income of foreign-controlled U.S. corporations. Journal of the American Taxation Association, 19: Supplement, forthcoming.

and D. Shackelford. 1997. Global organizations and taxes: An analysis of the dividend, interest, royalty, and management fee payments between U.S. multinationals' foreign affiliates. Journal of Accounting and Economics 24:2, forthcoming.

, and J. Wahlen. 1995. Bank differences in the coordination of regulatory capital, earnings, and taxes. Journal of Accounting Research 33: 263-291.

Cummins, J., S. Harrington, and B. Smith. 1980. An analysis of the impact of alternative rate regulatory systems on underwriting profitability in property-liability insurance. Presentation at the 1980 meetings of the American Risk and Insurance Association, Chicago.

and J. VanDerhei. 1979. A note on the relative efficiency of property-liability insurance distribution systems. Bell Journal of Economics 10: 709-719.

Froot, K. 1989. Consistent covariance matrix estimation with cross-sectional dependence and heteroskedasticity in financial data. Journal of Financial and Quantitative Analysis 333355 . 
Grubert, H., T. Goodspeed, and D. Swenson. 1993. Explaining the low taxable income of foreign-controlled companies in the U.S. in A. Giovanni, R. Hubbard, and J. Slemrod, eds. Studies in International Taxation. Chicago: University of Chicago Press: 237-275.

Guenther, D. 1994. The relation between tax rates and pre-tax returns: Direct evidence from the 1981 and 1986 tax rate reductions. Journal of Accounting \& Economics 18: 379-393.

Harris, D. 1993. The impact of U.S. tax law revision on multinational corporations' capital location and income-shifting decisions. Journal of Accounting Research 31: Supplement, 111-140.

, R. Morck, J. Slemrod, and B. Yeung. 1993. Income shifting in U.S. multinational corporations, in A. Giovanni, R. Hubbard, and J. Slemrod, eds. Studies in International Taxation. Chicago: University of Chicago Press: 277-307.

Harrington, S. 1984. The impact of rate regulation on prices and underwriting results in the property-liability insurance industry: A survey. Journal of Risk and Insurance 51: 577623.

Jacob, J. 1996. Taxes and transfer-pricing: Income shifting and the volume of intra-firm transfers. Journal of Accounting Research 34: 301-312.

Joskow, P. 1973. Cartels, competition, and regulation in the property-liability insurance industry, Bell Journal of Economics and Management Science 4: 375-427.

Klassen, K., M. Lang, and M. Wolfson. 1993. Geographic income shifting by multinational corporations in response to tax rate changes. Journal of Accounting Research 31: Supplement, 141-173.

and D. Shackelford. 1997. State and provincial corporate tax planning: Income shifting and sales apportionment factor management. University of North Carolina working paper.

Mayers, D. and C. Smith. 1988. Ownership structure across lines of property-casualty insurance. Journal of Law and Economics 31: 351-378.

1994. Managerial discretion, regulation, ad stock insurer ownership structure. Journal of Risk and Insurance 61: 638-655.

Petroni, K. and D. Shackelford. 1995. Taxation, regulation, and the organizational structure of property-casualty insurers. Journal of Accounting and Economics 20: 229-253.

Scholes, M. G. Wilson and M. Wolfson. 1990. Tax planning, regulatory capital planning, and financial reporting strategy for commercial banks. Review of Financial Studies 3: 625650 . 
Scholes, M. and M. Wolfson. 1992. Taxes and Business Strategy: A Planning Approach. Englewood Cliffs, N.J.: Prentice-Hall.

Shackelford, D. 1991. The market for tax benefits: Evidence from leveraged ESOPs, Journal of Accounting \& Economics 14: 117-145.

Sommer, D. 1996. The impact of firm risk on property-liability insurance prices, Journal of Risk and Insurance 63: 501-514.

Vines, C. 1996. Tax shifting in a regulated industry: An analysis of the property and casualty insurance industry. The Journal of the American Taxation Association 18: 48-71.

White, H. 1980. A heteroskedasticity-consistent covariance matrix estimator and a direct test for heteroskedasticity. Econometrica 48: 817-838.

Witt, R. and H. Miller. 1981. Price competition, regulation, and systematic underwriting risk in auto insurance markets. CPCU Journal 34: 174-189. and J. Urrutia. 1983. A comparative economic analysis of tort liability and no-fault compensation systems in automobile insurance. Journal of Risk and Insurance 50: 631669. 


\section{TABLE 1}

Descriptive statistics for the regression variables;

12,573 insurer-states, constructed from the 1993 state tax and regulatory filings of multistate property-casualty insurers.

\begin{tabular}{|c|c|c|c|c|c|c|c|}
\hline & Mean & Std. Dev. & Minimum & $25 \%$ & Median & $75 \%$ & Maximum \\
\hline PRICE & 1.61 & 0.59 & 0.50 & 1.18 & 1.56 & 2.01 & 3.00 \\
\hline ETR & 0.015 & 0.005 & 0.006 & 0.012 & 0.015 & 0.018 & 0.028 \\
\hline INCDUM & 0.10 & & & & & & \\
\hline EASYETR & 0.002 & 0.006 & 0 & 0 & 0 & 0 & 0.03 \\
\hline PREMRATE & 0.024 & 0.006 & 0 & 0.020 & 0.023 & 0.025 & 0.045 \\
\hline INCRATE & 0.006 & 0.020 & 0 & 0 & 0 & 0 & 0.14 \\
\hline RATEREG & 0.39 & & & & & & \\
\hline RESTRICT & 26 & 15 & 1 & 13 & 27 & 41 & 51 \\
\hline NOFAULT & 0.27 & & & & & & \\
\hline INSPOP & 0.29 & 0.27 & 0.03 & 0.11 & 0.19 & 0.31 & 1.24 \\
\hline DIRWRITE & 0.20 & & & & & & \\
\hline SIZE & 19.2 & 1.7 & 13.9 & 17.9 & 19.1 & 20.4 & 24.0 \\
\hline CAPITAL & 0.34 & 0.16 & -0.24 & 0.24 & 0.31 & 0.40 & 1.00 \\
\hline PORTRISK & 0.14 & 0.15 & 0 & 0.02 & 0.09 & 0.21 & 1.00 \\
\hline
\end{tabular}

PRICE is insurer i's total premiums earned less policyholder dividends divided by total losses incurred in state j; ETR is the greater of the total taxes collected from insurers in state $\mathrm{j}$ divided by the total premiums earned in state $\mathrm{j}$ or the total taxes collected from insurers in insurer $\mathrm{i}$ 's state of domicile divided by the total premiums earned in insurer i's state of domicile; INCDUM is a categorical variable equaling one if state $\mathrm{j}$ levies an income tax on insurer $i$, otherwise zero; EASYETR is ETR if insurer i writes more than 75 percent of its business in lines other than automobile, farm, fire, home, or workers' compensation, otherwise zero; PREMRATE is the greater of the premium tax rate in state $j$ or the premium tax rate in insurer i's state of domicile; INCRATE is the income tax rate applicable to insurers in state j; RATEREG is a categorical variable equaling one if state $\mathrm{j}$ maintains a system of prior approval regulation, state-made rates, or bureau rates, otherwise zero; RESTRICT is Conning \& Company's rating of the freedom to manage personal and commercial lines in state $\mathrm{j}$; NOFAULT is a categorical variable equaling one if state $\mathrm{j}$ has some form of no-fault automobile compensation law; DIRWRITE is a categorical variable equaling one if insurer $i$ is a direct writer; INSPOP is the number of insurers per 1000 people in state j; SIZE is the natural logarithm of insurer i's admitted assets; CAPITAL is insurer i's statutory surplus divided by total admitted assets; PORTRISK is the percentage of insurer i's total invested assets in equity, unoccupied real estate and mortgage loans. 
TABLE 2

Pearson correlation coefficients for the regression variables; 12,573 insurer-states,

Constructed from the 1993 state tax and regulatory filings of multistate property-casualty insurers.

\begin{tabular}{|c|c|c|c|c|c|c|}
\hline & PRICE & ETR & INCDUM & EASYETR & PREMRATE & INCRATE \\
\hline PRICE & & -0.03 & -0.03 & 0.01 & -0.01 & -0.03 \\
\hline ETR & -0.03 & & -0.23 & 0.11 & 0.47 & -0.21 \\
\hline INCDUM & -0.03 & -0.23 & & -0.03 & -0.23 & 0.95 \\
\hline EASYETR & 0.01 & 0.11 & -0.03 & & 0.08 & -0.03 \\
\hline PREMRATE & -0.01 & 0.47 & -0.23 & 0.08 & -0.21 \\
\hline INCRATE & -0.03 & -0.21 & 0.95 & -0.03 & -0.21 & \\
\hline RATEREG & -0.04 & 0.00 & -0.11 & 0.01 & 0.00 & -0.05 \\
\hline RESTRICT & -0.04 & 0.01 & 0.03 & 0.01 & 0.02 & 0.09 \\
\hline NOFAULT & -0.03 & -0.24 & 0.21 & -0.03 & -0.17 & 0.25 \\
\hline INSPOP & -0.01 & 0.15 & -0.20 & 0.03 & 0.07 & -0.18 \\
\hline DIRWRITE & -0.02 & -0.02 & -0.01 & 0.14 & -0.04 & -0.02 \\
\hline SIZE & -0.06 & -0.02 & -0.01 & -0.18 & -0.00 & 0.01 \\
\hline CAPITAL & 0.06 & 0.02 & 0.01 & 0.23 & 0.03 & -0.00 \\
\hline PORTRISK & 0.02 & 0.02 & -0.00 & 0.05 & 0.02 & 0.00 \\
\hline
\end{tabular}

Variables are defined in Table 1. Correlations $\geq 0.03(0.04)$ in absolute magnitude are significant at $>0.05(0.01)$. 
TABLE 3

Estimated coefficients (t-statistics) from regressions of insurance prices collected from 1993 state tax and regulatory filings of property-casualty insurers

\begin{tabular}{|c|c|c|c|c|c|c|c|}
\hline & $\begin{array}{l}\text { pred } \\
\text { sign }\end{array}$ & |-------- & B & $\begin{array}{c}\text { Multistate } \\
\mathrm{C}\end{array}$ & D & E & $\begin{array}{c}\text { Single-State } \\
\text { F }\end{array}$ \\
\hline \multicolumn{8}{|c|}{ TAX VARIABLES } \\
\hline ETR & $(-)$ & $\begin{array}{c}-5.33 \\
(-4.41) \\
\end{array}$ & $\begin{array}{c}-4.46 \\
(-3.65) \\
\end{array}$ & & $\begin{array}{c}-4.07 \\
(-3.07) \\
\end{array}$ & $\begin{array}{c}-5.04 \\
(-3.75) \\
\end{array}$ & $\begin{array}{c}2.47 \\
(0.24) \\
\end{array}$ \\
\hline INCDUM & (?) & $\begin{array}{l}-0.087 \\
(-4.84) \\
\end{array}$ & $\begin{array}{l}-0.087 \\
(-4.85) \\
\end{array}$ & & $\begin{array}{l}-0.063 \\
(-3.73) \\
\end{array}$ & $\begin{array}{l}-0.085 \\
(-4.64) \\
\end{array}$ & $\begin{array}{l}0.047 \\
(0.42) \\
\end{array}$ \\
\hline EASYETR & $(-)$ & & $\begin{array}{c}-5.35 \\
(-3.74) \\
\end{array}$ & & & & \\
\hline PREMRATE & $(-)$ & & & $\begin{array}{c}-1.83 \\
(-1.90) \\
\end{array}$ & & & \\
\hline INCRATE & $(-)$ & & & $\begin{array}{c}-0.94 \\
(-3.57)\end{array}$ & & & \\
\hline \multicolumn{8}{|l|}{ CONTROLS } \\
\hline Intercept & & $\begin{array}{c}1.93 \\
(22.3)\end{array}$ & $\begin{array}{c}1.97 \\
(22.7)\end{array}$ & $\begin{array}{c}1.87 \\
(21.5)\end{array}$ & & $\begin{array}{c}2.17 \\
(168.8)\end{array}$ & $\begin{array}{c}2.40 \\
(4.48)\end{array}$ \\
\hline RATEREG & $(-)$ & $\begin{array}{l}-0.035 \\
(-3.07) \\
\end{array}$ & $\begin{array}{l}-0.035 \\
(-3.09) \\
\end{array}$ & $\begin{array}{l}-0.026 \\
(-2.25) \\
\end{array}$ & $\begin{array}{l}-0.021 \\
(-1.91) \\
\end{array}$ & $\begin{array}{l}-0.034 \\
(-2.87) \\
\end{array}$ & $\begin{array}{l}-0.194 \\
(-2.18)\end{array}$ \\
\hline RESTRICT & $(-)$ & $\begin{array}{l}-0.001 \\
(-3.48) \\
\end{array}$ & $\begin{array}{l}-0.001 \\
(-3.50) \\
\end{array}$ & $\begin{array}{l}-0.002 \\
(-3.75) \\
\end{array}$ & $\begin{array}{l}-0.002 \\
(-5.04) \\
\end{array}$ & $\begin{array}{l}-0.001 \\
(-3.45) \\
\end{array}$ & $\begin{array}{l}0.003 \\
(0.90) \\
\end{array}$ \\
\hline NOFAULT & $(-)$ & $\begin{array}{l}-0.030 \\
(-2.36) \\
\end{array}$ & $\begin{array}{l}-0.030 \\
(-2.35) \\
\end{array}$ & $\begin{array}{l}-0.025 \\
(-1.92) \\
\end{array}$ & $\begin{array}{l}-0.028 \\
(-2.24) \\
\end{array}$ & $\begin{array}{l}-0.029 \\
(-2.27) \\
\end{array}$ & $\begin{array}{l}0.002 \\
(0.01)\end{array}$ \\
\hline INSPOP & $(-)$ & $\begin{array}{l}-0.068 \\
(-2.98)\end{array}$ & $\begin{array}{l}-0.067 \\
(-2.96)\end{array}$ & $\begin{array}{l}-0.072 \\
(-3.23)\end{array}$ & $\begin{array}{l}-0.088 \\
(-4.06)\end{array}$ & $\begin{array}{l}-0.062 \\
(-2.65)\end{array}$ & $\begin{array}{l}0.011 \\
(0.05)\end{array}$ \\
\hline DIRWRITE & $(-)$ & $\begin{array}{l}-0.033 \\
(-2.38) \\
\end{array}$ & $\begin{array}{l}-0.025 \\
(-1.84)\end{array}$ & $\begin{array}{l}-0.033 \\
(-2.39) \\
\end{array}$ & & $\begin{array}{l}-0.028 \\
(-1.47)\end{array}$ & $\begin{array}{l}0.142 \\
(1.39)\end{array}$ \\
\hline SIZE & $(-)$ & $\begin{array}{l}-0.012 \\
(-2.94)\end{array}$ & $\begin{array}{l}-0.014 \\
(-3.42)\end{array}$ & $\begin{array}{l}-0.011 \\
(-2.71)\end{array}$ & & $\begin{array}{l}-0.020 \\
(-3.77)\end{array}$ & $\begin{array}{l}-0.041 \\
(-1.40)\end{array}$ \\
\hline CAPITAL & $(+)$ & $\begin{array}{l}0.083 \\
(1.99)\end{array}$ & $\begin{array}{l}0.089 \\
(2.12)\end{array}$ & $\begin{array}{l}0.084 \\
(2.01)\end{array}$ & & & $\begin{array}{l}-0.038 \\
(-0.21)\end{array}$ \\
\hline PORTRISK & $(-)$ & $\begin{array}{l}0.129 \\
(3.12) \\
\end{array}$ & $\begin{array}{l}0.140 \\
(3.39)\end{array}$ & $\begin{array}{l}0.123 \\
(2.98) \\
\end{array}$ & & & $\begin{array}{l}-0.199 \\
(-0.82) \\
\end{array}$ \\
\hline $\operatorname{adj.} R^{2}$ & & 0.02 & 0.02 & 0.02 & 0.20 & 0.01 & 0.03 \\
\hline$n$ & & 12,573 & 12,573 & 12,573 & 12,573 & 12,573 & 180 \\
\hline
\end{tabular}

Variables are defined in Table 1.

Explanatory variables and sample

Column A: $\quad$ State taxes per premiums (ETR) and income tax indicator variable (INCDUM) with controls for previously documented price determinants (coefficients on insurer lines are not reported); examine multistate insurers;

Column B: same as A, except insurers are segregated by ease of managing taxes (EASYETR);

Column C: $\quad$ same as A, except estimated statutory premium tax rates (PREMRATE) and income tax rates (INCRATE);

Column D: $\quad$ same as A, except insurer-specific controls are replaced by categorical variables denoting each insurer;

Column E: $\quad$ same as A, except CAPITAL, PORTRISK and controls for the eight lines of business are excluded and t-statistics reflect Froot (1989) adjusted standard errors;

Column F: $\quad$ same as A, except examine single-state insurers. 